\title{
METODE STUDI KASUS : UPAYA-UPAYA GURU DALAM MENINGKATKAN MOTIVASI BELAJAR SISWA SMA NEGERI 14 PEKANBARU
}

\author{
Reski Yohanda
}

Fakultas Agama Islam (FAI) Universitas Islam Riau (UIR) Pekanbaru

Jl. Kaharuddin Nasution, No. 113, Perhentian Marpoyan Pekanbaru 28284

Email: rezkyyohanda11@gmail.com

\begin{abstract}
Abstrak : Tujuan penelitian ini adalah untuk mengukur sejauh mana tingkat pemahaman guru tentang bagaimana cara mengatasi masalah siswa yang didalam dirinya tertanam sifat pemalas disertai kurangnya minat belajar dan motivasi. Judul penelitian ini adalah Upaya Guru dalam Meningkatkan Motivasi Belajar Siswa Kelas XI pada Mata Pelajaran Pendidikan Agama Islam Di SMA Negeri 14 Pekanbaru. Permasalahan dalam penelitian ini adalah; 1) Bagaimana upaya Guru PAI di SMA Negeri 14 Pekanbaru dalam mengatasi masalah yang terdapat disetiap individu siswa?, 2) Apa saja faktor pendukung dan penghambat upaya guru dalam meningkatkan motivasi belajar siswa dalam belajar PAI pada siswa kelas XI Di SMA Negeri 14 Pekanbaru?, 3) Metode apakah yang digunakan guru dalam memacu motivas siswa dalam belajar?, 4) Apa saja permasalahan yang terjadi dalam proses belajar mengajar sehingga dibutuhkannya motivasi dalam belajar?, 5) Apakah dengan meningkatkan motivasi dalam belajar, ada pengaruhnya dalam proses belajar siswa?. Metode yang digunakan dalam penelitian ini adalah metode studi kasus, yaitu penelitian yang menyajikan informasi yang bertujuan untuk mengetahui tentang sesuatu hal secara mendalam. Maka dalam penelitian ini, peneliti akan menggunakan metode studi kasus untuk mengungkap tentang bagaimana upaya-upaya guru dalam meningkatkan motivasi belajar siswa di SMA Negeri 14 Pekanbaru.
\end{abstract}

Kata Kunci: motivasi belajar, metode studi kasus, upaya guru.

\begin{abstract}
The purpose of this study is to measure the extent of the teacher's understanding of how to deal with students' problems that are inherently lazy with a lack of interest in learning and motivation. The title of this research is Teacher's Efforts in Improving Student Learning Motivation in Class XI in Islamic Religious Education Subjects at SMA Negeri 14 Pekanbaru. The problems in this study are; 1) What is the effort of PAI teachers in Pekanbaru 14 High Schools in overcoming the problems found in each individual student ?, 2) What are the supporting and inhibiting factors of teacher efforts in increasing student motivation to learn PAI in class XI students in SMA Negeri 14 Pekanbaru ?, 3) What methods are used by teachers in stimulating student motivation in learning ?,4) What are the problems that occur in the learning process so
\end{abstract}


that motivation is needed in learning? 5) Does increasing motivation in learning have an effect on student learning? The method used in this research is the case study method, namely research that presents information that aims to find out about something in depth. So in this study, researchers will use the case study method to reveal how teachers' efforts to improve student motivation in SMA 14 Pekanbaru.

Keywords : learning motivation, case study methods, teacher efforts.

\section{Pendahuluan}

Manusia adalah makhluk individu dan makhluk sosial. Dalam hubungannya dengan manusia sebagai makhluk sosial, terkandung suatu maksud bahwa manusia bagaimanapun juga tidak dapat terlepas dari individu yang lain. Secara kodrati manusia akan selalu hidup bersamaan. Hidup bersama antar manusia akan berlangsung dalam berbagai bentuk komunikasi dan situasi. Berbagai bentuk interaksi, khususnya mengenai interaksi yang disengaja, ada istilah interaksi edukatif. Interaksi edukatif ini adalah interaksi yang berlangsung dalam satu tujuan pendidikan dan pengajaran. Mengajar bukan sekedar usaha untuk menyampaikan ilmu pengetahuan atau transfer limu saja, tetapi lebih dari itu adalah usaha menciptakan sistem lingkungan yang mempelajarkan subjek didik agar tujuan pengajaran dapat tercapai secara optimal.

Mengajar dalam pemahaman seperti ini perlu suatu strategi belajarmengajar yang tepat. Mutu pengajaran antara lain tergantung pada pemilihan strategi yang tepat bagi tujuan yang ingin dicapai, terutama dalam upaya mengembangkan kreatifitas dan inspirasi subjek didik. Untuk itu guru perlu mengembangkan kemampuan profesionalnya untuk program pengajaran dengan strategi belajar mengajar yang kaya dengan variasi dan inovasi. Interaksi belajar mengajar mengandung suatu arti adanya kegiatan interaksi dari tenaga pengajar yang melaksanakan tugas mengajar di pihak, dengan warga belajar (siswa, anak didik/subjek belajar) yang sedang melaksanakan kegiatan belajar dipihak lain. Interaksi antara pengajar dan warga belajar diharapkan merupakan proses motivasi. Maksudnya, bagaimana dalam proses interaksi itu pihak pengajar mampu memberikan dan mengembangkan motivasi serta reinforcement kepada pihak warga belajar/siswa/subjek pendidik, agar dapat melakukan kegiatan belajar mengajar secara optimal. Persoalan motivasi ini, dapat juga dikaitkan dengan persoalan minat. Minat diartikan sebagai suatu kondisi yang terjadi apabila seseorang melihat ciri-ciri atau arti sementara situasi yang dihubungkan dengan keinginan-keinginan atau kebutuhannya sendiri. Minat adalah satu faktor internal yang dapat mempengaruhi belajar siswa, pada dasarnya merupakan hal yang sangat fundamental dalam diri manusia, karena minat merupakan modal yang sangat pokok dalam melaksanakan suatu aktifitas. 
Manusia akan berhasil aktifitasnya apabila aktifitas itu dibarengi dengan minat yang tinggi, karena minat itu sendiri adalah gejala kejiwaan yang selalu berhubungan erat dengan sikap dan tingkah laku terhadap objek yang dihadapinya. Banyak pakar yang mengartikan bahwa minat timbul tidak secara tiba-tiba, melainkan timbul akibat partisipasi, pengalaman, kebiasaan pada waktu belajar atau bekerja. Jadi jelas bahwa soal minat akan selalu berkaitan dengan kebutuhan atau keinginan. Oleh karena itu yang penting bagaimana menciptakan kondisi tertentu agar siswa dapat selalu butuh dan ingin terus belajar. Sejatinya, didalam diri setiap siswa memiliki minat yang tinggi dalam belajar. Namun berdasarkan studi pendahuluan yang penulis lakukan ketika observasi di di SMA Negeri 14 Pekanbaru khususnya di kelas XI, ternyata banyak siswa yang belum bisa berpartisipasi secara aktif dalam proses pembelajaran yang dilaksanakan, serta belum memiliki minat yang besar dalam dirinya dalam mempelajari materi Pendidikan Agama Islam.

Hal ini bisa di buktikan dari rendahnya tingkat kemampuan siswa umtuk mengimplementasikan materi PAI tersebut dalam lingkungan sekolah, dan masih rendahnya motivasi belajar yang dicapai oleh siswa pada mata pelajaran tersebut. Semua ini dapat dipengaruhi oleh bermacam-macam latar belakang siswa, baik dari latar belakang pendidikan, keluarga, lingkungan, serta asumsi masyarakat yang menganggap bahwa pelajaran PAI adalah pelajaran yang sangat gampang untuk dipahami dan tidak perlu untuk dipelajari dengan serius. Oleh karena itu, permasalahan ini dianggap penting dan layak untuk diteliti. Karena peneliti ingin mengetahui faktor-faktor apa saja yang mempengaruhi tinggi rendahnya motivasi, usaha guru dalam meningkatkan motivasi anak yang kurang serta, mengetahui strategi-strategi yang di gunakan oleh guru guna membangkitkan motivasi belajar siswa serta faktor penghambat dan pendukungnya.

\section{Pengertian Metode Studi Kasus}

Studi kasus adalah sebuah eksplorasi dari "suatu sistem yang terikat" atau "suatu kasus/beragam kasus" yang dari waktu ke waktu melalui pengumpulan data yang mendalam serta melibatkan berbagai sumber informasi yang "kaya" dalam suatu konteks. Sistem terikat ini diikat oleh waktu dan tempat sedangkan kasus dapat dikaji dari suatu program, peristiwa, aktivitas atau suatu individu. Dengan perkataan lain, studi kasus merupakan penelitian dimana peneliti menggali suatu fenomena tertentu (kasus) dalam suatu waktu dan kegiatan (program, even, proses, institusi atau kelompok sosial) serta mengumpulkan informasi secara terinci dan mendalam dengan menggunakan berbagai prosedur pengumpulan data selama periode tertentu. Selanjutnya Creswell mengungkapkan bahwa apabila kita akan memilih studi untuk suatu kasus, dapat dipilih dari beberapa program studi atau sebuah program studi 
dengan menggunakan berbagai sumber informasi yang meliputi: observasi, wawancara, materi audio-visual, dokumentasi dan laporan.

Konteks kasus dapat "mensituasikan" kasus di dalam settingnya yang terdiri dari setting fisik maupun setting sosial, sejarah atau setting ekonomi. Sedangkan fokus di dalam suatu kasus dapat dilihat dari keunikannya, memerlukan suatu studi (studi kasus intrinsik) atau dapat pula menjadi suatu isu (isu-isu) dengan menggunakan kasus sebagai instrumen untuk menggambarkan isu tersebut (studi kasus instrumental). Ketika suatu kasus diteliti lebih dari satu kasus hendaknya mengacu pada studi kasus kolektif.

Untuk itu Lincoln Guba mengungkapkan bahwa struktur studi kasus terdiri dari masalah, konsteks, isu dan pelajaran yang dipelajari. Menurut Creswell, pendekatan studi kasus lebih disukai untuk penelitian kualitatif. Seperti yang diungkapkan oleh Patton bahwa kedalaman dan detail suatu metode kualitatif berasal dari sejumlah kecil studi kasus. ${ }^{1}$

Oleh karena itu penelitian studi kasus membutuhkan waktu lama yang berbeda dengan disiplin ilmu-ilmu lainnya. ${ }^{2}$ Tetapi pada saat ini, penulis studi kasus dapat memilih pendekatan kualitatif atau kuantitatif dalam mengembangkan studi kasusnya. Seperti yang dilakukan oleh Yin (1989) mengembangkan studi kasus kualitatif deskriptif dengan bukti kuantitatif. ${ }^{3}$ Merriam (1988) mendukung suatu pendekatan studi kasus kualitatif dalam bidang pendidikan. Hamel (1993) seorang sosiolog menunjukkan pendekatan studi kasus kualitatif untuk sejarah. Stakes (1995) menggunakan pendekatan ekstensif dan sistematis untuk penelitian studi kasus. Untuk itu Creswell menyarankan bahwa peneliti yang akan mengembangkan penelitian studi kasus hendaknya pertama-tama, mempertimbangan tipe kasus yang paling tepat. Kasus tersebut dapat merupakan suatu kasus tunggal atau kolektif, banyak tempat atau di dalamtempat, berfokus pada suatu kasus atau suatu isu (instrinsik-instrumental). Kedua, dalam memilih kasus yang akan diteliti dapat dikaji dari berbagai aspek seperti beragam perspektif dalam permasalahannya, proses atau peristiwa. Ataupun dapat dipilih dari kasus biasa, kasus yang dapat diakses atau kasus yang tidak biasa. Lebih lanjut Creswell mengemukakan

${ }^{1}$ Michael Quinn Patton, How to Use Qualitative Methods in Evaluation (London: SAGE Publications, 1991), hlm. 23

${ }^{2}$ Creswell mencontohkan penelitian Hamel (1993) yang mencoba melacak asal mula studi kasus ilmu sosial modern melalui antropologi dan sosiologi. Hamel mengutip studi Pulau Trobriand dari ahli antropologi Malinowksi, studi tentang keluarga dari sosiolog asal Perancis LePlay dan studi kasus di Universitas Chicago Jurusan Sosiologi pada tahun 1920-an dan 1930- an, yaitu studi yang dilakukan oleh Thomas \& Znaniecki tahun 1958 dengan judul The Polish in Europe and America sebuah sejarah dalam penelitian studi kasus kualitatif.

3 Robert K. Yin. (1989). Case Study Research Design and Methods. Washington: COSMOS Corporation 
beberapa "tantangan" dalam perkembangan studi kasus kualitatif sebagai berikut :

Pertama, Peneliti hendaknya dapat mengidentifikasi kasusnya dengan baik. Kedua, Peneliti hendaknya mempertimbangkan apakah akan mempelajari sebuah kasus tunggal atau multikasus.

Ketiga, Dalam memilih suatu kasus diperlukan dasar pemikiran dari peneliti untuk melakukan strategi sampling yang baik sehingga dapat pula mengumpulkan informasi tentang kasus dengan baik pula.

Keempat, Memiliki banyak informasi untuk menggambarkan secara mendalam suatu kasus tertentu. Dalam merancang sebuah studi kasus, peneliti dapat mengembangkan sebuah matriks pengumpulan data dengan berbagai informasi yang dikumpulkan mengenai suatu kasus.

Kelima, Memutuskan "batasan" sebuah kasus. Batasan-batasan tersebut dapat dilihat dari aspek waktu, peristiwa dan proses.

Creswell mengemukakan bahwa dalam studi kasus melibatkan pengumpulan data yang banyak karena peneliti mencoba untuk membangun gambaran yang mendalam dari suatu kasus. Untuk diperlukan suatu analisis yang baik agar dapat menyusun suatu deskripsi yang terinci dari kasus yang muncul. Seperti misalnya analisis tema atau isu, yakni analisis suatu konteks kasus atau setting dimana kasus tersebut dapat menggambarkan dirinya sendiri. Peneliti mencoba untuk menggambarkan studi ini melalui teknik seperti sebuah ronologi peristiwa-peristiwa utama yang kemudian diikuti oleh suatu perspektif yang terinci tentang beberapa peristiwa. Ketika banyak kasus yang akan dipilih, peneliti sebaiknya menggunakan analisis dalam-kasus yang kemudian diikuti oleh sebuah analisis tematis di sepanjang kasus tersebut yang acap kali disebut analisis silang kasus untuk menginterpretasi makna dalam kasus. ${ }^{4}$

\section{Bagaimana Penggunaan Teori Dan Pertanyaan Penelitian Dalam Studi Kasus?}

Studi kasus kualitatif menerapkan teori dalam cara yang berbeda. Creswell mengungkapkannya dengan contoh studi kasus kualitatif dari (Stake, 1995) tentang reformasi di Sekolah Harper yang menggambarkan sebuah studi kasus deskriptif dan berorientasi pada isu. Studi ini dimulai dengan mengemukakan isu tentang "reformasi sekolah", kemudian dilanjutkan dengan deskripsi sekolah, komunitas dan lingkungan. Selama isu suatu kasus masih berkembang, teori belum dapat digunakan dalam studi kasus ini. Menurut Creswell sebuah teori membentuk arah studi (Mc Cormick, 1994). Studi dimulai dengan definisi "non pembaca", kemudian dilanjutkan pada dasar teori bagi studi yang "dibingkai" dalam sebuah teori interaktif. Studi berlanjut

4 John W. Creswell. (1998). Qualitative Inquiry And Research Design: Choosing Among Five Traditions. London: SAGE Publications 
dengan melihat kemampuan dan ketidakmampuan membaca siswa akan memprediksi kegagalan dan keberhasilan siswa dalam membaca dan menulis. Hal ini berhubungan erat dengan faktor internal dan eksternal. Kemudian studi berlanjut dengan mengeksplorasi pengalaman seorang siswa yang berusia 81/2 tahun. Dalam kasus penembakan di kampus, kita tidak memposisikan studi di dalam dasar teori tertentu sebelum pengumpulan data, tetapi setelah pengumpulan data sehingga acapkali dikenal dengan teori-setelah.

Menurut Creswell dalam studi kasus kualitatif, seseorang dapat menyusun pertanyaan maupun sub pertanyaan melalui isu dalam tema yang dieksplorasi, juga sub pertanyaan tersebut dapat mencakup langkah-langkah dalam prosedur pengumpulan data, analisis dan konstruksi format naratif. Sub pertanyaan yang dapat memandu peneliti dalam melakukan penelitian studi kasus sebagai berikut : (1) Apa yang terjadi ?, (2) Siapa yang terlibat dalam respons terhadap suatu peristiwa tersebut ?, (3) Tema respons apa yang muncul selama 8 bulan mengikuti peristiwa ini?, (4) Konstruksi teori apa yang dapat membantu kita memahami respons di kampus ?, (5) Konstruksi apa yang unik dalam kasus ini ?. Sedangkan pertanyaan-pertanyaan prosedural adalah sebagai berikut : (1) Bagaimana suatu kasus dan peristiwa tersebut digambarkan ? (deskripsi kasus). (2) Tema apa yang muncul dari pengumpulan informasi tentang kasus ? (analisis materi kasus). (3) Bagaimana peneliti menginterpretasikan tema-tema dalam teori sosial dan psikologi yang lebih luas ? (pelajaran yang dipelajari dari kasus berdasarkan literatur).

\section{Bagaimana Pengumpulan Data Studi Kasus?}

Pengumpulan data dalam studi kasus dapat diambil dari berbagai sumber informasi, karena studi kasus melibatkan pengumpulan data yang "kaya" untuk membangun gambaran yang mendalam dari suatu kasus. Yin mengungkapkan bahwa terdapat enam bentuk pengumpulan data dalam studi kasus yaitu: (1) dokumentasi yang terdiri dari surat, memorandum, agenda, laporan-laporan suatu peristiwa, proposal, hasil penelitian, hasil evaluasi, kliping, artikel; (2) rekaman arsip yang terdiri dari rekaman layanan, peta, data survei, daftar nama, rekaman-rekaman pribadi seperti buku harian, kalender dsb; (3) wawancara biasanya bertipe open-ended; (4) observasi langsung; (5) observasi partisipan dan (6) perangkat fisik atau kultural yaitu peralatan teknologi, alat atau instrumen, pekerjaan seni dll.12 Lebih lanjut Yin mengemukakan bahwa keuntungan dari keenam sumber bukti tersebut dapat dimaksimalkan bila tigprinsip berikut ini diikuti, yaitu: (1) menggunakan bukti multisumber; (2) menciptakan data dasar studi kasus, seperti : catatan-catatan studi kasus, dokumen studi kasus, bahan-bahan tabulasi, narasi; (3) memelihara rangkaian bukti.13 Sedangkan menurut (Asmussen \& Creswell) menampilkan pengumpulan data melalui matriks sumber informasi untuk pembacanya. Matriks ini mengandung empat tipe data yaitu: wawancara, observasi, dokumen dan materi audio-visual untuk kolom dan bentuk spesifik dari 
informasi seperti siswa, administrasi untuk baris. Penyampaian data melalui matriks ini ditujukan untuk melihat kedalaman dan banyaknya bentuk dari pengumpulan data, sehingga menunjukkan kekompleksan dari kasus tersebut. Penggunaan suatu matriks akan bermanfaat apabila diterapkan dalam suatu studi kasus yang kaya informasi. Lebih lanjut Creswell mengungkapkan bahwa wawancara dan observasi merupakan alat pengumpul data yang banyak digunakan oleh berbagai penelitian. Hal ini menunjukkan bahwa kedua alat itu merupakan pusat dari semua tradisi penelitian kualitatif sehingga memerlukan perhatian yang tambahan dari peneliti.

\section{Bagaimana Analisis Data Studi Kasus?}

Menganalisis data studi kasus adalah suatu hal yang sulit karena strategi dan tekniknya belum teridentifikasikan secara baik. Tetapi setiap penelitian hendaknya dimulai dengan strategi analisis yang umum yang mengandung prioritas tentang apa yang akan dianalisis dan mengapa. Demikianpun dengan studi kasus, oleh karena itu Creswell memulai pemaparannya dengan mengungkapkan tiga strategi analisis penelitian kualitatif, yaitu: strategi analisis menurut (Bogdan \& Biklen, 1992), (Huberman \& Miles, 1994) dan (Wolcott, 1994).14 Menurut Creswell, untuk studi kasus seperti halnya etnografi analisisnya terdiri dari "deskripsi terinci" tentang kasus beserta settingnya. Apabila suatu kasus menampilkan kronologis suatu peristiwa maka menganalisisnya memerlukan banyak sumber data untuk menentukan bukti pada setiap fase dalam evolusi kasusnya. Terlebih lagi untuk setting kasus yang "unik", kita hendaknya menganalisa informasi untuk menentukan bagaimana peristiwa itu terjadi sesuai dengan settingnya.

Stake mengungkapkan empat bentuk analisis data beserta interpretasinya dalam penelitian studi kasus, yaitu: (1) pengumpulan kategori, peneliti mencari suatu kumpulan dari contoh-contoh data serta berharap menemukan makna yang relevan dengan isu yang akan muncul; (2) interpretasi langsung, peneliti studi kasus melihat pada satu contoh serta menarik makna darinya tanpa mencari banyak contoh. Hal ini merupakan suatu proses dalam menarik data secara terpisah dan menempatkannya kembali secara bersama-sama agar lebih bermakna; (3) peneliti membentuk pola dan mencari kesepadanan antara dua atau lebih kategori. Kesepadanan ini dapat dilaksanakan melalui tabel $2 \times 2$ yang menunjukkan hubungan antara dua kategori; (4) pada akhirnya, peneliti mengembangkan generalisasi naturalistik melalui analisa data, generalisasi ini diambil melalui orang-orang yang dapat belajar dari suatu kasus, apakah kasus mereka sendiri atau menerapkannya pada sebuah populasi kasus.

Lebih lanjut Creswell menambahkan deskripsi kasus sebagai sebuah pandangan yang terinci tentang kasus. Dalam studi kasus "peristiwa penembakan", kita dapat menggambarkan peristiwa itu selama dua minggu, menyoroti pemain utamanya, tempat dan aktivitasnya. Kemudian 
mengumpilkan data ke dalam 20 kategori dan memisahkannya ke dalam lima pola. Dalam bagian akhir dari studi ini kita dapat mengembangkan generalisasi tentang kasus tersebut dipandang dari berbagai aspek, dibandingkan, dibedakan dengan literatur lainnya yang membahas tentang kekerasan di kampus. Dari paparan di atas dapat diuraikan bahwa "persiapan terbaik" untuk melakukan analisis studi kasus adalah memiliki suatu strategi analisis. Tanpa strategi yang baik, analisis studi kasus akan berlangsung sulit karena peneliti "bermain dengan data" yang banyak dan alat pengumpul data yang banyak pula. Untuk Robert K. Yin merekomendasikan enam tipe sumber informasi seperti yang telah dikemukakan pada bagian pengumpulan data. Tipe analisis dari data ini dapat berupa analisis holistik, yaitu analisis keseluruhan kasus atau berupa analisis terjalin, yaitu suatu analisis untuk kasus yang spesifik, unik atau ekstrim.

Lebih lanjut Yin membagi tiga teknik analisis untuk studi kasus, yaitu (1) penjodohan pola, yaitu dengan menggunakan logika penjodohan pola. Logika seperti ini membandingkan pola yang didasarkan atas data empirik dengan pola yang diprediksikan (atau dengan beberapa prediksi alternatif). Jika kedua pola ini ada persamaan, hasilnya dapat menguatkan validitas internal studi kasus yang bersangkutan; (2) pembuatan eksplanasi, yang bertujuan untuk menganalisis data studi kasus dengan cara membuat suatu eksplanasi tentang kasus yang bersangkutan dan (3) analisis deret waktu, yang banyak dipergunakan untuk studi kasus yang menggunakan pendekatan eksperimen dan kuasi eksperimen.

Creswell mengemukakan bahwa dalam studi kasus melibatkan pengumpulan data yang banyak karena peneliti mencoba untuk membangun gambaran yang mendalam dari suatu kasus. Untuk diperlukan suatu analisis yang baik agar dapat menyusun suatu deskripsi yang terinci dari kasus yang muncul. Seperti misalnya analisis tema atau isu, yakni analisis suatu konteks kasus atau setting dimana kasus tersebut dapat menggambarkan dirinya sendiri. Peneliti mencoba untuk menggambarkan studi ini melalui teknik seperti sebuah

\section{Bagaimana Melakukan Standar Kualitas Dan Verifikasi Dalam Studi Kasus?}

Stake (1995) menyatakan bahwa suatu studi kasus memerlukan verifikasi yang ekstensif melalui triangulasi dan member chek. Stake menyarankan triangulasi informasi yaitu mencari pemusatan informasi yang berhubungan secara langsung pada "kondisi data" dalam mengembangkan suatu studi kasus. Triangulasi membantu peneliti untuk memeriksa keabsahan data melalui pengecekan dan pembandingan terhadap data. Lebih lanjut Stake "menawarkan" triangulasi dari Denzin (1970) yang membedakan empat macam tringulasi sebagai teknik pemeriksaan yang memanfaatkan penggunaan sumber data, peneliti, teori dan metodologi. Untuk member check, Stake merekomendasikan peneliti untuk melakukan pengecekan kepada anggota yang 
terlibat dalam penelitian studi kasus ini dan mewakili rekan-rekan mereka untuk memberikan reaksi dari segi pandangan dan situasi mereka sendiri terhadap data yang telah diorganisasikan oleh peneliti. Lebih lanjut Stake memberikan sebuah "daftar cek kritik" untuk laporan studi kasus dan membaginya ke dalam 20 kriteria untuk menilai sebuah laporan studi kasus yang baik sebagai berikut: (1) Apakah laporan itu mudah dibaca?, (2) Apakah laporan itu tepat secara umum, yaitu tiap kalimat berkontribusi pada keseluruhan laporan?, (3) Apakah laporan tersebut memiliki sebuah struktur konseptual (misalnya tema atau isu)?, (4) Apakah isu-isunya dikembangkan secara serius dan ilmiah?, (5) Apakh kasusnya didefinisikan secara baik?, (6) Apakah terdapat cerita pada presentasi?, (7) Apakah pembaca memberikan masukkan dari beberapa pengalaman yang mewakilinya?, (8) Apakah kutipankutipan digunakan secara efektif ?, (9) Apakah heading, angka-angka, instrumen, lampiran, indeks digunakan secara efektif ?, (10) Apakah laporan tersebut diedit dengan baik?, (11) Apakah pembaca disarankan untuk membuat pernyataan baik itu lewat atau di bawah interpretasi?, (12) Apakah perhatian yang memadai telah dibayar pada beragam konteks?, (13) Apakah data mentah yang baik akan ditampilkan?, Apakah sumber data dipilih dengan baik dan jumlahnya memadai?, Apakah observasi dan interpretasi yang muncul telah ditriangulasi?, Apakah peranan dan sudut pandang peneliti muncul dengan baik?, Apakah "sifat" audiens yang dimaksud akan nampak?, (14) Apakah empati ditujukan untuk semua aspek?, (15) Apakah maksud pribadi penulis dikaji?, (16)Apakah laporan tersebut muncul dan beresiko pada individu?.

Sedangkan Robert K.Yin mengemukakan prosedur laporan studi kasus sebagai berikut : (1) kapan dan bagaimana memulai suatu tulisan; (2) identifikasi kasus: nyata atau tersamar ?; (3) tinjauan ulang naskah studi kasus: suatu prosedur validasi.22 Untuk menyusun suatu cerita pada studi kasus, menurut (Asmussen \& Creswell, 1995) mencoba mengkaji studi kasus kualitatif tentang "respon kampus pada seorang siswa penembak" melalui laporan kasus substantif dari Lincoln \& Guba. Format Lincoln \& Guba ini dimulai dengan membuktikan penjelasan masalah, sebuah deskripsi yang terinci mengenai konteks atau setting serta proses yang diamati, sebuah diskusi tentang elemen penting dan pada akhirnya menyusun hasil penelitian melalui "pelajaran yang dipelajari.

Pertama, setelah memperkenalkan studi kasus dengan masalah kekerasan di kampus, kemudian penulis memberikan deskripsi secara terinci mengenai setting dan kronologis peristiwa. Kemudian beralih kepada tema penting yang muncul dalam analisis. Tema ini terbagi ke dalam dua tema yakni: tema organisasional dan tema psikologis atau sosio-psikologi.

Kedua, mengumpulkan data melalui wawancara dengan informan, observasi, dokumentasi dan materi audio-visual. Dengan menanyakan halhal sebagai berikut : Apa yang terjadi?, Apa yang dilibatkan dalam respon 
peristiwa tersebut?, Tema respon apa yang muncul selama 8 bulan?, Konstruksi teoritis apa yang dikembangkan secara unik pada kasus ini?.

Ketiga, naratif menggambarkan peristiwa dengan menghubungkan konteks pada

bingkai kerja yang lebih luas.

Keempat, melakukan verifikasi kasus dengan menggunakan beberapa sumber data untuk suatu tema melalui triangulasi dan pengecekkan anggota.

\section{Kritik terhadap Studi Kasus}

Pendekatan studi kasus tidak lepas dari kritik. (Idowu, 2016) menegaskan bahwa mayoritas kritik terhadap metodologi dalam studi kasus. Kritik yang paling sering adalah ketergantungan pada kasus tunggal yang menjadikannya tidak dapat digenerali-sasi. Studi sejumlah kecil kasus dalam studi kasus tidak dapat digunakan untuk membangun keandalan temuan. Penelitian studi kasus dianggap mengandung bias terhadap verifikasi, dengan kata lain studi kasus memiliki kecenderungan untuk mengkonfirmasi ide-ide yang terbentuk sebelumnya oleh peneliti. Kritik tersebut diarahkan pada statistik dan bukan gene-ralisasi analitik yang menjadi dasar studi kasus, di mana dalam generalisasi analitik, teori yang dikembangkan sebelumnya digunakan sebagai template untuk memban-dingkan hasil empiris dari studi kasus. Generalisasi baik desain tunggal maupun ganda, dibuat untuk teori dan bukan populasi (Yin, 2002). Tujuan dari penelitian studi kasus adalah menetapkan parameter dan kemudian diterapkan pada semua penelitian. Validitas konstruk sangat berma-salah dalam penelitian studi kasus (Tellis, 1997), terdapat tiga solusi untuk mengatasi-nya, yaitu memperbanyak sumber bukti, membangun rantai bukti dan memiliki laporan rancangan studi kasus yang ditinjau oleh informan kunci.

Beberpa penelitian menggunakan judul studi kasus, contoh penelitian (Budi, 2006:75-86) tentang studi kasus kekerasan terhadap perempuan dalam rumah tangga di kota Yogyakarta kurang dapat memberikan gambaran 'bagaimana' kekerasan dalam rumah tangga itu terjadi, tidak menyebutkan desain studi kasus yang dimaksudkan, analisis data dilakukan secara kuantitatif,"5. Demikian pula dengan penelitian (Nurmala, Anam \& Suyono, 2006:28-37) tentang studi kasus perempuan lesbian (butchy) di Yogyakarta kurang dapat memberikan kesimpulan "bagaimana dinamika psikologis perempuan lesbian yang dimaksud, sumber data tunggal berasal dari wawancara, hasil penelitian belum merujuk pada parameter penelitian". 6 Satu

5 Budi, S. H. (2006). Studi kasus tentang kekerasan terhdap perempuan dalam rumah tangga di kota Yogyakarta. Humanitas, 3(2), 75-86.

${ }^{6}$ Nurmala, D., Anam, C., \& Suyono, H. (2006). Studi kasus perempuan lesbian (butchy) di Yogyakarta. Indonesian Psychological Journal, 3(1), 28-37 
artikel penelitian (Novita \& Siswati, 2010:102-116) menggunakan terminologi desain studi kasus tunggal dalam sebuah studi eksperimen pengaruh social stories terhadap "ketrampilan sosial anak". ${ }^{7}$ Demikian pula banyak peneli-tian yang menggunakan 'studi kasus di luar atrikel yang digunakan dalam pembahasan ini, untuk menjelaskan terminologi konteks atau tempat, seperti studi kasus di PT. X, di sekolah A tetapi di dalam laporan penelitian atau publikasi artikel berisi analisis kuantitatif. Beberapa penelitian tersebut belum menggunakan studi kasus sebagai sebuah metode dalam penelitian.

\section{Pengertian Motivasi Belajar}

Motivasi belajar merupakan dua hal yang sangat berhubungan dan saling mempengaruhi. Motivasi berasal dari kata "motif" yang berarti sebagai daya upaya yang mendorong seseorang untuk melakukan sesuatu. Motif juga berarti keadaan pribadi orang yang mendorong individu untuk melakukan aktifitasaktifitas tertentu guna mencapai suatu tujuan. ${ }^{8}$ Menurut Mc. Donald yang dikutip oleh Oemar Hamalik motivasi merupakan suatu perubahan energi di dalam pribadi seseorang yang ditandai dengan timbulnya afektif (perasaan) dan reaksi untuk mencapai tujuan (motivation is an energy change within the person characterized by affectve arousal anticivatory goal reaction). ${ }^{9}$ Motivasi dapat juga diartikan sebagai daya penggerak yang telah menjadi aktif pada saat-saat tertentu.

Dalam arti lain konsep motivasi dijelaskan oleh Hull yang dikutip oleh suciati (2006) motivasi merupakan dorongan untuk memenuhi atau memuaskan kebutuhan agar tetap hidup. ${ }^{10}$ Dalam proses belajar motivasi sangat diperlukan sebab seseorang yang tidak memiliki motivasi dalam belajar mustahil akan melakukan aktifitas belajar dan secara otomatis kebutuhan akan belajar tidak terpenuhi. Belajar adalah suatu proses usaha yang dilakukan individu untuk memperoleh suatu perubahan tingkah laku yang baru secara keseluruhan sebagai hasil pengalaman individu itu sendiri dengan lingkungannya. ${ }^{11}$ Walaupun belajar disebutkan sebagai upaya individu untuk memperoleh perubahan tingkah laku namun tidak semua perubahan individu

\footnotetext{
${ }^{7}$ Novita., \& Siswati. (2010). Pengaruh social stories terhadap keterampilan sosial anak dengan Attention-Deficit Hyper-activity Disorder (ADHD): Studi eksperimental desain kasus tunggal di Sekolah Alam Ar-Ridho Semarang. Jurnal Psikologi Undip, 8(2), 102-116. doi: 10.14710/jpu.8.2.102-116.

${ }^{8}$ Sumadi Suryabrata, psikologi pendidikan, ( Jakarta, Raja GrafindoPersada, 2006), hal. 70

${ }^{9}$ Oemar Hamalik, Proses Belajar Mengajar, ( Jakarta, Bumi Aksara cet. 5, 2006), hal. 158

${ }^{10}$ Suciati, dkk, Belajar Dan Pembelajaran 2, (Jakarta, universitas terbuka, 2006), hal. 3.3

${ }^{11}$ Slameto, Belajar Dan Faktor-Faktor Yang Mempengaruhinya, ( Jakarta, Rhineka Cipta, 2003), hal. 2
} 
dikatakan belajar karena belajar memiliki sifat-sifat tertentu yang membedakannya dengan kegiatan lain. Menurut muhibbin perubahan ditandai dengan perubahan yang bersifat intensional, perubahan itu positif dan aktif dan perubahan itu efektif dan fungsional. ${ }^{12} \mathrm{Hal}$ ini sejalan dengan pendapat Drs. H. Baharuddin, M.Pd dan Esa Nur Wahyuni, M. Pd dalam bukunya teori belajar dan pembelajaran menyatakan bahwa "belajar merupakan proses manusia untuk mencapai berbagai macam kompetensi, keterampilan, dan sikap". ${ }^{13}$ Seseorang dikatakan belajar apabila memenuhi ciri belajar sebagai berikut:

Pertama, Belajar ditandai dengan adanya perubahan tingkah laku. Ini berarti, bahwa hasil belajar dapat diamati dari tingkah laku yaitu adanya perubahan tingkah laku dari tidak tahu menjadi tahu, dari tidak terampil menjadi terampil. Tanpa mengamati tingkah laku hasil belajar kita tidak akan dapat mengetahui ada tidaknya hasil belajar.

Kedua, Perubahan tingkah laku relative permanent. Ini berarti, bahwa perubahan tingkah laku yang terjadi karena belajar untuk waktu tertentu akan tetap atau tidak berubah-ubah.

Ketiga, Perubahan tingkah laku tidak harus segera dapat diamati pada saat proses belajar sedang berlangsung, perubahan perilaku tersebut bersifat potensial.

Keempat, Perubahan tingkah laku berupa hasil latihan atau pengalaman.

Kelima, Pengalaman atau latihan itu dapat memberikan penguatan. Sesuatu yang memperkuat itu akan memberikan semangat atau dorongan untuk mengubah tingkah laku.

Jadi, belajar sebagai perubahan tingkah laku ini terjadi setelah siswa melaksanakan kegiatan pembelajaran yang kemudian mendapatkan hasil berupa penguasaan pengetahuan ataupun keterampilan tertentu. Maka motivasi belajar adalah keseluruhan daya penggerak di dalam diri siswa yang menimbulkan kegiatan belajar, yang menjamin kelangsungan kegiatan belajar dan yang memberikan arah pada kegiatan belajar sehingga tujuan yang dikehendaki oleh subjek belajar itu dapat tercapai. Dengan adanya motivasi dalam diri siswa maka proses pembelajaran akan berjalan sesuai dengan yang diharapkan. Karena motivasi akan mendorong siswa untuk melakukan kegiatan belajar. Motivasi merupakan hal yang sangat penting dalam proses pembelajaran (motivation is an essential condition of learning). Hasil belajar akan menjadi optimal, kalau ada motivasi. Jadi motivasi akan senantiasa menentukan intensitas usaha belajar bagi para siswa.

${ }^{12}$ Muhibbin Syah, Psikologi Belajar, ( Jakarta, Raja Grafindo Persada, 2004), hal. 174

13 Baharuddin, Esa Nur Wahyuni, Teori Belajar Dan Pembelajaran, (Jogjakarta, Ar-Ruzz Media, 2008), hal. 11 
Motivasi berhubungan erat dengan kebutuhan, Semakin besar kebutuhan seseorang akan sesuatu maka akan semakin kuat motivasi untuk mencapai sesuatu itu. kemudian dalam hubungannya dengan kegiatan belajar, yang penting bagaimana menciptakan kondisi atau suatu proses yang mengarahkan siswa melakukan aktifitas belajar. Dalam hal ini sudah barang tentu peran guru sangat penting. Bagaimana guru melakukan usaha-usaha untuk dapat menumbuhkan dan memberikan motivasi agar anak didiknya melakukan aktifitas belajar dengan baik. Dalam hal ini apabila seorang guru mampu memberikan motivasi dengan baik maka akan diperoleh hasil yang baik pula.

Motivasi siswa dalam belajar dapat bersifat internal atau eksternal. Motivasi internal/intrinsik adalah dorongan dari dalam diri individu berupa minat kesenangan, kebutuhan untuk melakukan suatu aktifitas. Sedangkan motivasi eksternal/ekstrinsik adalah dorongan yang berasal dari luar diri individu.

\section{Upaya meningkatkan motivasi belajar}

Untuk memperoleh pecapaian tujuan belajar yang optimal, guru dituntut kreatif dalam meningkatkan motivasi belajar siswa. Menurut (Wina Sanjaya), ada beberapa upaya yang harus dilakukan oleh guru untuk meningkatkan motivasi belajar siswa, diantaranya : Pertama, Memperjelas tujuan yang ingin dicapai. Kedua, Membangkitkan minat siswa.

Beberapa cara dapat dilakukan untuk membangkitkan minat belajar siswa: (1) Hubungkan bahan pelajaran yang akan diajarkan dengan kebutuhan siswa, (2) Sesuaikan materi pelajaran dengan tingkat pengalaman dan kemampuan siswa, (3) Gunakan berbagai model dan strategi pembelajaran secara bervariasi misalnya diskusi, kerja kelompok, eksperimen, demonstrasi, dan lain sebagainya.

Di SMA Negeri 14 Pekanbaru, khususnya dikelas XI MIPA. Ada beberapa siswa yang memiliki kasus yaitu kurangnya motivasi dalam belajar. Setelah kami melakukan sesi wawancara kepada salah satu guru bidang studi agama Islam, yaitu ibu Ermayani, S.Pd. dalam sesi wawancara yang kami lakukan, kami menemukan banyak sekali permasalahan yang terjadi pada siswa sehingga berdampak pada proses belajar mengajarnya disekolah. Ada 8 pertanyaan yang kami ajukan, adapun pertanyaan berikut adalah: (1) apakah ada pengaruh banyaknya mata pelajaran tambahan yang membuat siswa malas belajar? (2) Apakah pihak sekolah memperbolehkan siswa membawa smartphone ke sekolah?, (3) Apakah ada metode yang guru gunakan dalam proses pembelajaran yang membuat siswa kurang minatnya dalam belajar?, (4) Apakah ada faktor masalah lingkungan yang membuat siswa malas belajar?, (5) Apakah ada faktor masalah keluarga yang membuat siswa malas belajar, contohnya broken home?, (6) Apakah ada faktor guru yang membuat siswa malas belajar? Contohnya guru yang suka marah., (7) Apakah ada faktor 
pergaulan yang membuat siswa malas belajar? (8) Bagaimana menurut ibu guru sendiri tentang siswa yang tidak memiliki motivas dalam belajar?. Dalam pertanyaan tersebut, ibu guru Ermayani, S.Pd. memaparkan jawaban tersebut seperti;

Pertama, apakah ada pengaruh banyaknya mata pelajaran tambahan yang membuat siswa malas belajar? Menurut ibu Ermayani, banyaknya mata pelajaran tambahan seperti matematika perminatan, ekstrakurikuler dan hal lain semacamnya merupakan kebutuhan bagi para siswa dalam proses pembelajaran agar dalam pembelajaran pokok mereka terbantu dan cepat mengerti dengan diberinya jam pembelajaran, tentunya jam pembelajaran ini diimbangi dengan jam istirahat, sehingga proses belajar mengajar dapat ter-realisasi dengan baik. Hanya saja sebagian siswa yang kurang pandai terhadap salah satu mata pelajaran tembahan, mereka merasa terbebani dan timbul sifat malas karena tidak mengerti, seharusnya dengan ada jam tambahan bisa membuat mereka yang tidak mengarti jadi mengerti.

Kedua, apakah pihak sekolah memperbolehkan siswa membawa smartphone ke sekolah? Menurut ibu Ermayani, sebenarnya sekolah tidak membenarkan para siswa menggunakan smartphone saat proses belajar mengajar sedang berlangsung, bukan tidak boleh membawanya kesekolah, hanya saja sekarang di zaman yang serba modren ini, banyak pembelajaran yang membutuhkan alat bantu sebagai sumber pembelajaran, salah satunya adalah smartphone, jadi ada sebagian pembelajaran yang ketika membutuhkan smartphone sebagai media pembelajaran, maka guru memperbolehkannya menggunakannya dalam pembelajaran tersebut berlangsung. Akan tetapi, banyak para siswa yang menyalah gunakan kesempatan ini dengan membuka sosial media, game bahkan youtube untuk melihat berita yang tidak aka kaitannya dengan proses belajar mengajar, lemahnya pengawasan guru tersebutlah yang membuat pihak sekolah membatasi penggunaan smartphone di sekolah.

Ketiga, apakah ada metode yang guru gunakan dalam proses pembelajaran yang membuat siswa kurang minatnya dalam belajar? Menurut ibu Ermayani, selama ini sepengetahuan ibu belum ada, tetapi ada banyak keluhan yang terasa bagi para siswa saat proses belajar mengajar berlangsung guru lupa membawa media pembelajaran, sehingga pembelajaranpun terganggu, maklum kata ibu Ermayani, guru juga seorang manusia, dan manusia tidak luput dari sifat lupa dan kesalahan, akan tetapi, ibu Ermayani melanjutkan dengan melihat kondisi tersebut, bahwa pendidikan di Indonesia, khususnya di SMA Negeri 14 Pekanbaru belum siap dalam mengatasi problem guru.

Keempat, apakah ada faktor masalah lingkungan yang membuat siswa malas belajar? Menurut ibu Ermayani, inilah faktor terbesar saat ini, karena lingkunga adalah tempat dimana seorang anak tumbuh dan berkembang, 
lingkunganlah yang membentuk karakter para peserta didik, sebagai contoh, jika seorang anak tumbuh dilingkungan yang masyarakatnya rajin shalat berjama'ah 5 waktu dimesjid, maka anak itu akan selalu shalat 5 waktu dimesjid. Kenapa? Karena lingkunganlah yang membentuknya seperti itu, lingkunganlah yang mengajarkannya bahwa kewajiban umat Islam adalah melakukan shalat 5 waktu dimesjid. Sebaliknya juga, jika seorang anak tumbuh dilingkungan brandalan, makan anak tersebut bisa dipastikan akan menjadi brandalan jug, karena pergaulan yang membuatnya mau tidak mau seperti itu, karena tuntutan lingkungan dan adaptasi lingkungan.

Kelima, apakah ada faktor masalah keluarga yang membuat siswa malas belajar, contohnya broken home? Menurut ibu Ermayani, keluarga adalah pendidikan pertama bagi seorang anak, keluargalah yang membentuk seorang anak. Jika terdapat broken home dalam sebuah keluarga, maka anak juga akan terlibat didalamnya, terlibat karena anak juga bagian dari keluarga, urusan yang seharusnya belum iya mengetahuinya dan memikirkannya jadi membuatnya berfikir dengan tidak seharusnya, pemikiran inilah yang menciptakannya menjadi anak yang malas melakukan sesuatu, karena dia mengalami kondisi dimana kebahagiannya hilang dan merasa hidup ini tidak berarti, inilah yang membuat seorang siswa yang keluarganya broken home jadi siswa yang kehilangan motivasi dan merasa menyerah dalam hidup. Seharusnya hal semacam ini belum boleh difikirkan oleh pelajar, apa lagi pelajar SMA yang rentan terhadap suatu problem.

Keenam, apakah ada faktor guru yang membuat siswa malas belajar? Contohnya guru yang suka marah. Menurut ibu Ermayani, guru marah bukan berarti membenci muridnya, guru marah pasti karna guru itu sayang kepada muridnya dan tidak mau muridnya memiliki masa depan yang kelam karena menyia-nyiakan masa depannya disaat orang lain tidak seberuntungnya dapat belajar, seperti bermain-main dalam proses belajar mengajar, karena pendidikan itu mahal hargannya dan siswa tidak menghargainnya dengan bercanda tawa dalam pembelajaran, boleh bercanda tapi ada saatnya, kata ibu Ermayani.

Ketujuh, apakah ada faktor pergaulan yang membuat siswa malas belajar? Menurut ibu Ermayani, pergaulan merupakan tempat dimana seorang anak mengenal duniannya dan mengenal jadi dirinya, jadi jika seorang anak yang bijak, yang tahu tentang ajaran agama dan dirumah orang tuanya selalu mendidiknya, maka dia tidak akan mudah terpengaruh dengan faktor pergaulan, karna pergaulan ada yang baik dan ada yang buruk, ini adalah pr besar bagi orang tua dan guru dalam mengawasi pergaulan siswa dan anak mereka, agar peserta didik tidak terperosok kedalam pergaulan yang buruk.

Kedelapan, bagaimana menurut ibu guru sendiri tentang siswa yang tidak memiliki motivas dalam belajar? Menurut ibu Ermayani, tidak ada siswa yang tidak memiliki motivasi dalam belajar, hanya saja mereka belum 
menemukan motivasi mereka dalam belajar, contohnya ada siswa yang termotivasi dalam belajar karna ia memiliki cita-cita menjadi seorang dokter, maka dia mengejar cita-citanya dengan belajar bersungguh-sungguh. Terkadang sulit mengarahkan siswa untuk menentukan tujuan hidupnya, karena semua peserta didik memiliki fashion sendiri dalam menjalani hidup. Disinialh guru dituntut aktif dan kreatif dengan bagaimana cara menemukan fashion mereka dan mengarahkannya, disinilah beratnya menjadi seorang guru.

\section{Kesimpulan}

Studi kasus sebagai sebuah metode memberikan kerangka atau prosedur penelitian yang harus diikuti. Yin (2002) secara rigid mengharuskan peneliti untuk pengikuti prosedur penelitian yang ditetap-kan bahkan ketika peneliti mengubah desain maka peneliti perlu kembali pada prosedur awal. Studi kasus menjadi berguna apabila seseorang/peneliti ingin memahami suatu permasalahan atau situasi tertentu dengan amat mendalam dan dimana orang dapat mengidentifikasi kasus yang kaya dengan informasi, kaya dalam pengertian bahwa suatu persoalan besar dapat dipelajari dari beberapa contoh fenomena dan biasanya dalam bentuk pertanyaan. Studi kasus pada umumnya berupaya untuk menggambarkan perbedaan individual atau variasi "unik" dari suatu permasalahan.

Suatu kasus dapat berupa orang, peristiwa, program, insiden kritis/unik atau suatu komunitas dengan berupaya menggambarkan unit dengan mendalam, detail, dalam konteks dan secara holistik. Untuk itu dapat dikatakan bahwa secara umum, studi kasus lebih tepat digunakan untuk penelitian yang berkenaan dengan how atau why . Penekanan studi kasus adalah pada kedalaman dan kerincian: wawancara mendalam, penggambaran secara rinci dan pengungkapkan kasus dengan sungguh-sungguh melalui penerapan teori dalam cara yang berbeda, yakni tidak memposisikan studi di dalam dasar teori tertentu sebelum pengumpulan data, tetapi setelah pengumpulan data sehingga acapkali dikenal dengan teori-setelah. Demikian pun dalam pengumpulan datanya yang diambil dari berbagai sumber informasi, karena studi kasus melibatkan pengumpulan data yang "kaya" untuk membangun gambaran yang mendalam dari suatu kasus. Analisis datanya memerlukan banyak sumber data untuk menentukan bukti pada setiap fase dalam evolusi kasusnya. Terlebih lagi untuk setting kasus yang "unik", kita hendaknya menganalisa informasi untuk menentukan bagaimana peristiwa itu terjadi sesuai dengan settingnya. Sedangkan dalam penulisan laporannya, studi kasus membentuk struktur yang "lebih besar" dalam bentuk naratif tertulis.

Hal ini disebabkan suatu studi kasus menggunakan teori dalam deskripsikan kasus atau beberapa analisis untuk menampilkan perbandingan kasus silang atau antar tempat. Untuk itu disarankan bahwa untuk menyusun laporan studi kasus menyusun laporan studi kasus seorang peneliti hendaknya 
menyusun rancangan beberapa bagian laporan (misalnya bagian metodologi) daripada menunggu sampai akhir proses analisis data. Studi kasus juga memerlukan verifikasi yang ekstensif melalui triangulasi dan member chek sehingga dapat membantu peneliti untuk memeriksa keabsahan data melalui pengecekan dan pembandingan terhadap data.

Sebagai guru, kita mesti paham karakter para peserta didik dan juga kita harus bisa membaca situasi, jika ada seorang peserta didik yang mengalami masalah atau tidak konsentrasi dalam pembelajaran, kita harus cepat mengambil langkah untuk memperhatikan dan menanyakan apa sebabnya dan menemukan solusinya, karena sebagai guru kita merupakan orang tua kedua bagi mereka, maka selama para perserta didik berada dilingkungan sekolah saat proses belajar mengajar, mereka adalah tanggung jawab kita bersama.

\section{Daftar Pustaka}

Michael Quinn Patton, How to Use Qualitative Methods in Evaluation (London: SAGE Publications, 1991), hlm. 23

Creswell mencontohkan penelitian Hamel (1993) yang mencoba melacak asal mula studi kasus ilmu sosial modern melalui antropologi dan sosiologi. Hamel mengutip studi Pulau Trobriand dari ahli antropologi Malinowksi, studi tentang keluarga dari sosiolog asal Perancis LePlay dan studi kasus di Universitas Chicago Jurusan Sosiologi pada tahun 1920-an dan 1930- an, yaitu studi yang dilakukan oleh Thomas \& Znaniecki tahun 1958 dengan judul The Polish in Europe and America sebuah sejarah dalam penelitian studi kasus kualitatif.

Robert K. Yin. (1989). Case Study Research Design and Methods. Washington: COSMOS Corporation

John W. Creswell. (1998). Qualitative Inquiry And Research Design: Choosing Among Five Traditions. London: SAGE Publications

Budi, S. H. (2006). Studi kasus tentang kekerasan terhdap perempuan dalam rumah tangga di kota Yogyakarta. Humanitas, 3(2), 75-86.

Nurmala, D., Anam, C., \& Suyono, H. (2006). Studi kasus perempuan lesbian (butchy) di Yogyakarta. Indonesian Psychological Journal, 3(1), 28-37

Novita., \& Siswati. (2010). Pengaruh social stories terhadap keterampilan sosial anak dengan Attention-Deficit Hyper-activity Disorder (ADHD): Studi eksperimental desain kasus tunggal di Sekolah Alam Ar-Ridho Semarang. Jurnal Psikologi Undip, 8(2), 102-116. doi: 10.14710/jpu.8.2.102-116.

Sumadi Suryabrata, psikologi pendidikan, ( Jakarta, Raja GrafindoPersada, 2006), hal. 70 
Oemar Hamalik, Proses Belajar Mengajar, ( Jakarta, Bumi Aksara cet. 5, 2006), hal. 158

Suciati, dkk, Belajar Dan Pembelajaran 2, (Jakarta, universitas terbuka, 2006), hal. 3.3

Slameto, Belajar Dan Faktor-Faktor Yang Mempengaruhinya, ( Jakarta, Rhineka Cipta, 2003), hal. 2

Muhibbin Syah, Psikologi Belajar, ( Jakarta, Raja Grafindo Persada, 2004), hal. 174

Baharuddin, Esa Nur Wahyuni, Teori Belajar Dan Pembelajaran, (Jogjakarta, Ar-Ruzz Media, 2008), hal. 11 